\title{
Somatomedins/insulin-like growth factors, their receptors and binding proteins are present during mouse embryogenesis
}

\author{
ERIC P. SMITH' ${ }^{1}$, THOMAS W. SADLER ${ }^{2}$ and A. J. D'ERCOLE ${ }^{1}$ \\ ${ }^{1}$ Department of Pediatrics and ${ }^{2}$ Department of Anatomy, School of Medicine, 355 Medical Sctence Research Building, 206H, \\ Unversity of North Carolina, Chapel Hill, North Carolina 27514, USA
}

\begin{abstract}
Summary
Somatomedins/insulin-like growth factors (Sm/IGFs) are considered to have important roles in regulating fetal growth; however, because of limited quantities of tissue, few studies have been performed on their effects on embryonic growth. To assess a potential role for these factors, we evaluated mouse embryonic tissues for the presence of Sm/IGF and insulin receptors and Sm/IGF-binding proteins by chemical affinity labelling. In addition, we measured extractable $\mathrm{Sm}-\mathrm{C} / \mathrm{IGF}$-I radioimmunoactivity in mouse embryonic tissues. Finally, we compared these data with those from the embryonal carcinoma cell line, PC13. All embryos from day 9 (3-4 somites) to day 12 (45 somites) possessed both $\mathrm{Sm}-\mathrm{C} / \mathrm{IGF}-\mathrm{I}$ and IGF-II receptors in apparent greater abundance than insulin receptors. The visceral yolk sac appeared to have proportionally more insulin receptors than the corre-
\end{abstract}

sponding embryonic tissue. Extracts from the embryos contained immunoreactive Sm-C/IGF-I and binding proteins of $30-45 \times 10^{3} M_{\mathrm{r}}$. PC13 cells possessed all three receptors and the apparent abundance of the insulin and IGF-II receptors was reduced after differentiation was induced with retinoic acid. PC13 cells released both immunoreactive Sm-C/IGF-I- and Sm-C/IGF-I-binding proteins into their medium. When differentiated, the binding proteins resembled the native ones extracted from the intact embryos. The presence of $\mathrm{Sm} / \mathrm{IGF}$ activity, receptors and binding proteins in early embryogenesis suggests a role for these factors in embryonic growth. The PC13 cell line appears to only partially reflect normal development.

Key words: somatomedin, insulin-like growth factors, somtatomedin-binding proteins, mouse embryo.

\section{Introduction}

The somatomedins/insulin-like growth factors (Sm/IGFs), peptide mitogens with structural homology to insulin, are considered to have important roles in the regulation of fetal growth (Underwood \& D'Ercole, 1984; Milner \& Hill, 1984). Few studies have been performed with embryonic tissues, however, primarily because of the limited quantities of tissue available for study. Studies in the embryonic chick have demonstrated specific binding of somatomedin-C/insulin-like growth factor-I (Sm-C/IGF-I) to day- 2 chick embryos and detectable insulin-specific binding on day 3 , stages of embryonic development corresponding to approximately days 11 and 13 in the rat (Bassas, de Pablo, Lesniak \& Roth, 1985): Rosenblum, Mattson \& Heyner (1986) recently showed that insulin-specific binding could be detected in the murine morula and blastocyst, suggesting a role for insulin in early development. Because the presence of specific receptors suggests that a target cell has the capacity to respond to a ligand, we evaluated early embryonic tissues for the presence of $\mathrm{Sm} / \mathrm{IGF}$ and insulin receptors employing a chemical affinity labelling technique. We also evaluated the embryonal carcinoma cell line, PC13 (Rees, Adamson \& Graham, 1979; Adamson \& Hogan, 1984; Heath, Bell \& Rees, 1981), for these same parameters, because this cell line differentiates in response to retinoic acid in a fashion that has features similar to the intact embryo. In addition, to judge whether Sm/IGFs are synthesized by embryonic tissues and embryonal carcinoma cells, and thus available for interaction with receptors, we measured Sm-C/IGF-I immunoreactivity in extracts of embryonic tissues and in media from cultured embryonal carcinoma cells. Finally, we evaluated both intact embryos and PC13 cells for the presence of Sm/IGF-binding proteins. 


\section{Materials and methods}

\section{Reagents}

Sm-C/IGF-I and insulin-like growth factor II (IGF-II) were purified from Cohn fraction IV of human plasma by previously described methods (Svoboda \& Van Wyk, 1985; Smith et al. 1987) and porcine momomeric insulin was a gift from Eli Lilly Co. Each peptide was iodinated with $\left[{ }^{125} \mathrm{I}\right] \mathrm{NaI}$ (New England Nuclear Corp., Boston, MA) using a chloramine-T method (Furlanetto, Underwood, Van Wyk \& D'Ercole, 1977) and the specific activity of each ranged from 200 to $400 \mu \mathrm{Ci} \mu \mathrm{g}^{-1}$. For competition studies with radiolabelled Sm-C/IGF-I and insulin, the same preparation of unlabelled peptide was used, whereas for competition with labelled IGF-II, Multiplication Stimulating Activity (MSA) (Collaborative Research, Bedford, MA), the rate homologue of human IGF-II, was employed. Disuccinimidal suberate (DSS) (Pierce Chemical Co., Rockford, IL), Dulbecco's modified essential medium (DMEM) (Gibco Laboratories, Grand Island, NY), Kodak X-omat AR\% film (Eastman Kodak, Rochester, NY), porcine swine gelatin (Sigma Chemical Company, St. Louis, MO), retinoic acid (Sigma) and fetal calf serum (Hyclone Laboratories, Denver, CO), T150 tissue culture flasks (Corning Glass Works, Corning, NY), $35 \mathrm{~mm}$ culture dishes (Corning), bovine serum albumin (BSA), fraction $\mathrm{V}$ (free of Sm-C/IGF-I radioimmune activity: Sigma), porcine pancreatic trypsin, type II, (lot 15F-0414: Sigma) were purchased. The molecular weight standards for sodium dodecyl sulphate polyacrylamide gel electrophoresis (SDS-PAGE) were myosin $\left(200 \times 10^{3} M_{\mathrm{r}}\right)$, phosphorylase-B $\left(97.4 \times 10^{3} M_{\mathrm{r}}\right.$, bovine serum albumin $\left(68 \times 10^{3} M_{\mathrm{r}}\right)$, ovalbumin $\left(43 \times 10^{3} M_{\mathrm{r}}\right)$, lactoglobulin $\left(18.4 \times 10^{3} M_{\mathrm{r}}\right)$ and lysozyme $\left(14.3 \times 10^{3} M_{\mathrm{r}}\right)$ (Bethesda Research Laboratories, Bethesda, MD).

\section{Embryos}

Mouse embryos of ICR strain were obtained from pregnant female mice at 9-12 days gestation, determined by the observation of a vaginal plug on the morning after mating (day 1). These days encompass most of the period of organogenesis, from neurulation (3-4 somites, day 9) to vascularization of the yolk sac (17-18 somites) through establishment of the chorioallantoic placenta (27-31 somites) and limb bud stages (45 somites, day 12) of development. Decidual bodies were dissected from the uterine horns into Tyrode's solution followed by careful dissection of the embryo from the surrounding visceral yolk sac and placenta. In day- 9 embryos, the embryos and visceral yolk sac could not be separated completely, resulting in some visceral yolk-sac contamination of the day- 9 embryo samples. Day-19 liver from mouse fetuses was also dissected into Tyrode's solution. Finally, blastocysts were flushed with Tyrode's solution from uteri of 4- to 5-day gestation pregnant Swiss Webster mice. All the tissues were frozen at $-70^{\circ} \mathrm{C}$ until use.

\section{PC13 cells}

The PC13 cells (a generous gift from Eileen Adamson) were grown in DMEM with $10 \%$ fetal calf serum supplemented with penicillin, 100 i.u. $\mathrm{ml}^{-1}$, and streptomycin,
$100 \mu \mathrm{g} \mathrm{ml}^{-1}$, in $\mathrm{T} 150$ flasks that were coated with $0 \cdot 1 \%$ swine gelatin prior to plating. The medium was changed every 3 days. The cultures were incubated at $37^{\circ} \mathrm{C}$ in a humidıfied atmosphere containing $5 \% \mathrm{CO}_{2}$ and $95 \%$ air. The cells were passed using $0 \cdot 1 \%$ trypsin in phosphatebuffered saline (PBS) and plated at a split ratio of 1:10. Differentiation of PC13 cells was accomplished by plating at subconfluent densities of approximately 4000 cells $\mathrm{cm}^{-2}$ in 0.3 mm-retinoic acid for 7 days (Heath \& Deller, 1983; Adamson \& Hogan, 1984) with a medium change on day 3 and day 6 . To obtain conditioned medium, day-7 confluent cultures were washed twice with Hank's balanced salt solution (HBSS), and then incubated in DMEM with $0.01 \%$ BSA and antibiotic for $24 \mathrm{~h}$. Following collection, the medium was centrifuged at $5000 \mathrm{~g}$ to remove cellular debris and frozen at $-20^{\circ} \mathrm{C}$ until use. PC13 cells for affinity labelling were plated in $35 \mathrm{~mm}$ dishes at a density of 20000 cells per dish. Labelling was performed at 7 days as described below.

\section{Preparation of membranes}

Frozen tissue was suspended in membrane buffer $(0.25 \mathrm{M}$ sucrose, $10 \mathrm{~mm}$-Tris-HCl, 1.0 mm-EDTA, pH 7.4) and allowed to stand for $3-4 \mathrm{~h}$ at $4^{\circ} \mathrm{C}$. The tissues were then disrupted with a manual ground glass homogenizer in $0.5 \mathrm{ml}$ of buffer. The homogenate was centrifuged at $800 \mathrm{~g}$ and the supernatant, containing the bulk of the particulate membrane fraction was pooled with the supernatant of a second homogenization of the original pellet. The pooled supernatant was centrifuged at $12000 \mathrm{~g}$ for $10 \mathrm{~min}$ and resuspended in $0.01 \mathrm{~m}$-phosphate buffer, $\mathrm{pH} 7.4$. This constituted the membrane fraction and was stored at $-70^{\circ} \mathrm{C}$ until use. Protein concentration was estimated by the method of Lowry (Lowry, Rosebrough, Farr \& Randall, 1951). The supernatant was also stored at $-70^{\circ} \mathrm{C}$ to assess the presence of soluble binding proteins that are found predominantly in this fraction. Due to limited number of blastocysts, whole homogenates were used for their affinity labelling.

\section{Affinity labelling}

Labelling of membrane preparations was performed as previously reported (Chernausek, Jacobs \& Van Wyk, 1981) with some modification (Smith et al. 1987). Briefly, membrane protein suspended in Hepes binding buffer (120 mm-NaCl, $5 \mathrm{~mm}-\mathrm{KCl}, 1.2 \mathrm{~mm}-\mathrm{MgSO}_{4}, 8 \mathrm{~mm}$-glucose, $100 \mathrm{~mm}$-Hepes), $\mathrm{pH} 7 \cdot 8$, containing $0.1 \% \mathrm{BSA}$ was incubated at $4^{\circ} \mathrm{C}$ for $12-18 \mathrm{~h}$ with ${ }^{125} \mathrm{I}$-ligand $\left(2.0 \times 10^{5}\right.$ cts $\min ^{-1}$ ) alone and with various concentrations of unlabelled peptides in a final volume of $200 \mu \mathrm{l}$. The samples were then centrifuged at $12000 \mathrm{~g}$ for $5 \mathrm{~min}$ followed by resuspension in Hepes binding buffer, $\mathrm{pH} 7 \cdot 4$, without BSA. Freshly prepared DSS in $10 \mu$ l of dimethyl sulphoxide (DMSO) was added to each sample resulting in a final concentration of $0.1 \mathrm{~mm}$. The samples were immediately vortexed and allowed to stand at room temperature for $15-30 \mathrm{~min}$. The samples were then centrifuged at $12000 \mathrm{~g}$ for $5 \mathrm{~min}$ and resuspended in $100 \mu \mathrm{l}$ of gel sample buffer $(0.0625 \mathrm{M}$-Tris- $\mathrm{HCl}, \mathrm{pH} 6.8$, with $1 \%$ SDS, $8 \%$ glycerol, and $0.1 \%$ bromophenol blue) in the presence or absence of the reducing agent 2 -mercaptoethanol $(2 \%, \mathrm{vol} / \mathrm{vol})$ and boiled for $3 \mathrm{~min}$ before electrophoresis. 
PC13 cells were affinity labelled following previously described methods (Clemmons et al. 1986) with some minor modifications. Briefly, confluent cultures in $35 \mathrm{~mm}$ dishes were washed twice with PBS. ${ }^{125} \mathrm{I}$-ligand, $500000 \mathrm{cts}$ $\mathrm{min}^{-1}$ per dish with or without unlabelled peptide in a final volume of $0.8 \mathrm{ml}$ of Hepes binding buffer, $\mathrm{pH} 7.8$, with $0.1 \%$ BSA, was added to the dish and incubated overnight at $4^{\circ} \mathrm{C}$. The buffer was aspirated followed by a wash with PBS at $4^{\circ} \mathrm{C}$. DSS at a final concentration of $0.1 \mathrm{~mm}$ in $0.8 \mathrm{ml}$ of Hepes binding buffer, $\mathrm{pH} 7 \cdot 4$, without BSA was added for $15 \mathrm{~min}$ at room temperature. The reaction was stopped with 3 vol. of $10 \mathrm{~mm}$-Tris-HCl, $1.0 \mathrm{~mm}$-EDTA for $5 \mathrm{~min}$. After aspirating the stop solution, the sample was solubilized in $100 \mu \mathrm{l}$ of sample buffer, transferred with aid of a disposable spatula to a $1.5 \mathrm{ml}$ microfuge tube (Sarstedt, W. Germany), boiled for $3 \mathrm{~min}$ and electrophoresed.

Binding proteins in the conditioned medium and in the soluble fraction of tissue homogenates were affinity labelled as reported earlier (Clemmons et al. 1986). Briefly, $50 \mu \mathrm{l}$ of conditioned medium or embryonic tissue supernatant were incubated for $1 \mathrm{~h}$ with ${ }^{125}$ I-ligands and various concentrations of unlabelled peptides. Hepes binding buffer, $\mathrm{pH} 7 \cdot 8$, was added to result in a final total volume of $80 \mu \mathrm{l}$. Cross-linking was accomplished by the addition of $10 \mu \mathrm{l}$ DSS in DMSO to give a final concentration of $0 \cdot 1 \mathrm{~mm}$. After incubation at room temperature for $30 \mathrm{~min}$, five times volume of gel sample buffer was added, followed by boiling for $3 \mathrm{~min}$ and electrophoresis.

\section{Electrophoresis}

Electrophoresis was performed using the method of Laemmli (Laemmli, 1970). 3-14\% or 6-14\% linear gradient or $6 \%$ polyacrylamide slab gels were used containing $0.1 \%$ SDS. After electrophoresis at constant voltage of $125 \mathrm{~V}$ overnight at room temperature, the gels were dried under a vacuum and exposed to radiogram film using Dupont Cronex Lightening Plus intensifying screens at $-70^{\circ} \mathrm{C}$ for $5-7$ days for the receptor preparations and $3-5$ days for the binding protein gels. The blastocyst gels were exposed for 2 months.

\section{Quantitation of Sm-C/IGF-I in embryos and PC13- conditioned medium}

Sm-C/IGF-I activity was extracted from day-10 and -14 embryos according to previously described methods (D'Ercole, Stiles \& Underwood, 1984). Conditioned medium from PC13 cells were assayed in a Sm-C/IGF-I radioimmunoassay using human Sm-C/IGF-I as the standard (Furlanetto et al. 1977).

\section{Results}

\section{Embryo receptors and binding proteins}

Particulate tissue fractions from day- $9,-10,-11$ and -12 embryos were each separately affinity labelled with each of the three ${ }^{125}$ I-labelled peptides (insulin, Sm-C/IGF-I and IGF-II). As there were no apparent differences in the affinity-labelled complexes among the days tested, Fig. 1 shows an autoradiogram of

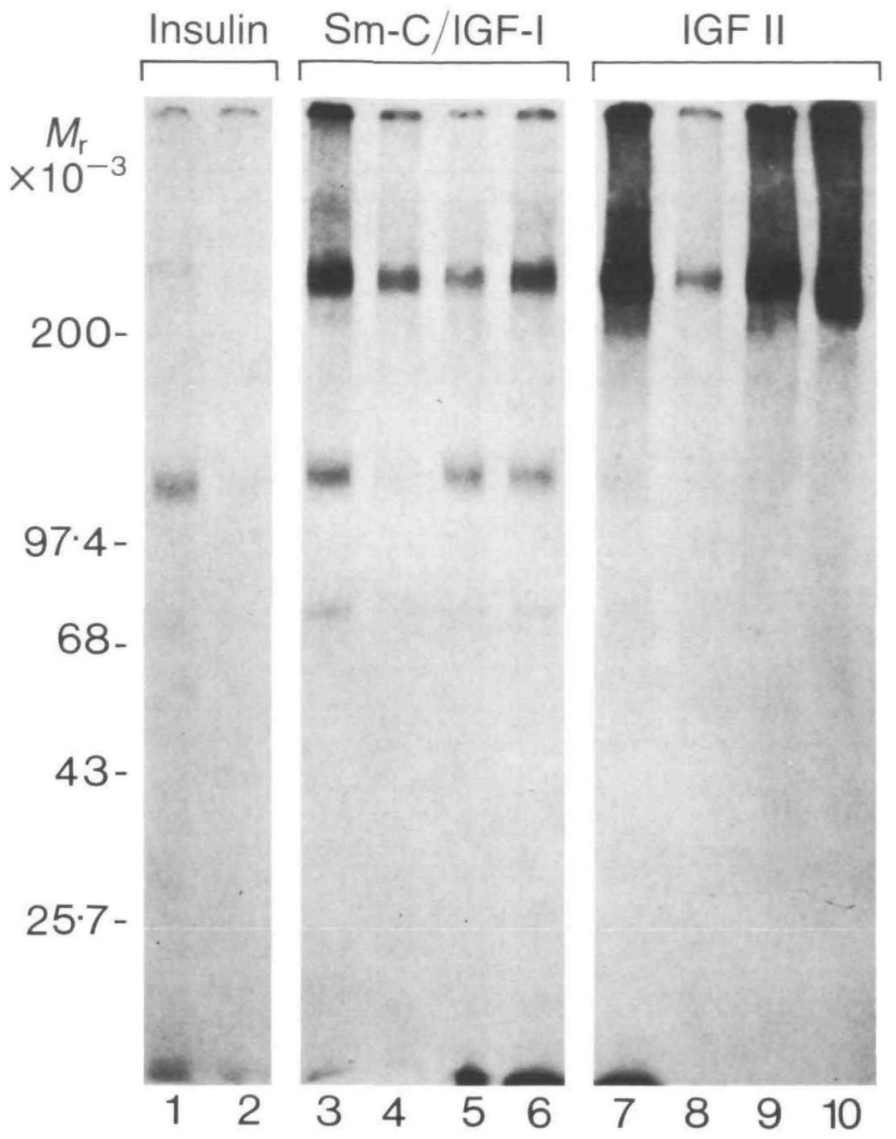

Fig. 1. Radiolabelled insulin, Sm-C/IGF-I and IGF-II affinity cross-linked to day-10 gestation embryonic membrane preparations. Radiolabelled complexes were resolved on 3-14\% SDS-PAGE and autoradiographed. The migration of molecular weight standards $\left(\times 10^{-3}\right)$ is depicted on the legend to the left. For ${ }^{125}$ I-insulin (lanes 1 and 2) $200 \mu \mathrm{g}$ membrane protein was analysed, while for ${ }^{125} \mathrm{I}-\mathrm{Sm}-\mathrm{C} / \mathrm{IGF}-\mathrm{I}$ (lanes 3-6) and ${ }^{125}$ I-IGF-II (lanes 7-10) $50 \mu \mathrm{g}$ was used. Except for lane 10, samples were reduced with $2 \% 2$-mercaptoethanol. In addition to the ${ }^{125} \mathrm{I}$ ligands, insulin $\left(100 \mathrm{ng} \mathrm{ml}^{-1}\right)$ was present during the incubation of samples shown in lanes 2 and 6, unlabelled Sm-C/IGF-I $\left(100 \mathrm{ng} \mathrm{m}^{-1}\right)$ in lanes 4 and 9 , and MSA in lanes $5\left(500 \mathrm{ng} \mathrm{ml}^{-1}\right)$ and $8\left(1 \mu \mathrm{g} \mathrm{ml}^{-1}\right)$.

affinity-labelled day-10 embryo membranes and is representative of each of the 9- to 12-day gestation tissues studied. Under reducing conditions, a ${ }^{125} \mathrm{I}$ insulin affinity-labelled complex (Fig. 1, lanes 1 and 2) with a relative migration of about $130000 M_{\mathrm{r}}$ $(130 \mathrm{~K})$ was judged to be specific because its labelling intensity was substantially reduced when the crosslinking was performed in the presence of $100 \mathrm{ng} \mathrm{ml}^{-1}$ unlabelled insulin (Fig. 1, lane 2). These features are typical of the alpha or binding subunit of the insulin receptor, described in other tissues (Czech, 1982). Under the same conditions, ${ }^{125} \mathrm{I}-\mathrm{Sm}-\mathrm{C} / \mathrm{IGF}-\mathrm{I}$ crosslinked to two species of about $135 \mathrm{~K}$ and $250 \mathrm{~K}$ (Fig. 1, lanes 3-6). The $135 \mathrm{~K}$ complex has characteristics of 
the alpha subunit of the type I Sm/IGF receptor (Czech, 1982): the labelling intensity is reduced more effectively by competition with unlabelled SmC/IGF-I, $100 \mathrm{ng} \mathrm{ml}^{-1}$ (lane 4), than by either MSA, $500 \mathrm{ng} \mathrm{ml}^{-1}$ (lane 5), or insulin, $100 \mathrm{ng} \mathrm{ml}^{-1}$ (lane 6), and the migration is significantly slower than the $\left[{ }^{125} \mathrm{I}\right]$ insulin-labelled complex (Stuart, Pietrzyk, Siu \& Furlanetto, 1984). The $250 \mathrm{~K}$ complex appears to represent ${ }^{125} \mathrm{I}-\mathrm{Sm}-\mathrm{C} / \mathrm{IGF}-\mathrm{I}$ binding to the type II $\mathrm{Sm} / \mathrm{IGF}$ receptor, because this complex migrates identically to the reduced complex affinity labelled with ${ }^{125}$ I-IGF-II (Fig. 1, lanes 7-9), is reduced in intensity by competition with unlabelled MSA more effectively than is the $135 \mathrm{~K}$ complex (Fig. 1, lane 5), and is not significantly altered by competition with unlabelled insulin (Fig. 1, lane 6).

${ }^{125}$ I-IGF-II crosslinks to a specifically labelled complex of about $250 \mathrm{~K}$ under reducing conditions and about $220 \mathrm{~K}$ under nonreducing conditions (Fig. 1, lanes 7 and 10, respectively). Unlabelled MSA competes for ${ }^{125} \mathrm{I}$-IGF-II binding to the type II subunit (Fig. 1, lane 8), whereas unlabelled Sm-C/IGF-I
(100 $\mathrm{ng} \mathrm{ml}^{-1}$ ) does not effectively compete for binding (lane 9). The relative migration of the reduced and unreduced complexes, and the specificity of binding are characteristic of the type II Sm/IGF receptor described in other systems (Czech, 1982), though effective competition with MSA appeared to require high concentrations. The type I and II $\mathrm{Sm} /$ IGF receptors appear substantially more abundant than the insulin receptor, because they are each more intensely labelled than the insulin receptor, even when four times less membrane protein ( $50 \mu \mathrm{g}$ versus $200 \mu \mathrm{g}$ ) was employed.

In contrast to embryonic tissues, the visceral yolk sac (days 10-12) appears to have more abundant insulin receptors. Fig. 2 shows an autoradiogram comparing affinity-labelled complexes in day-12 visceral yolk sacs and embryos, and day-19 fetal liver. The alpha subunit $(130 \mathrm{~K})$ of the insulin receptor is minimally labelled in the embryonic tissues compared with more intense labelling of visceral yolk sac and liver. The alpha subunit of Sm-C/IGF-I receptor, on the other hand, is only convincingly appreciated in

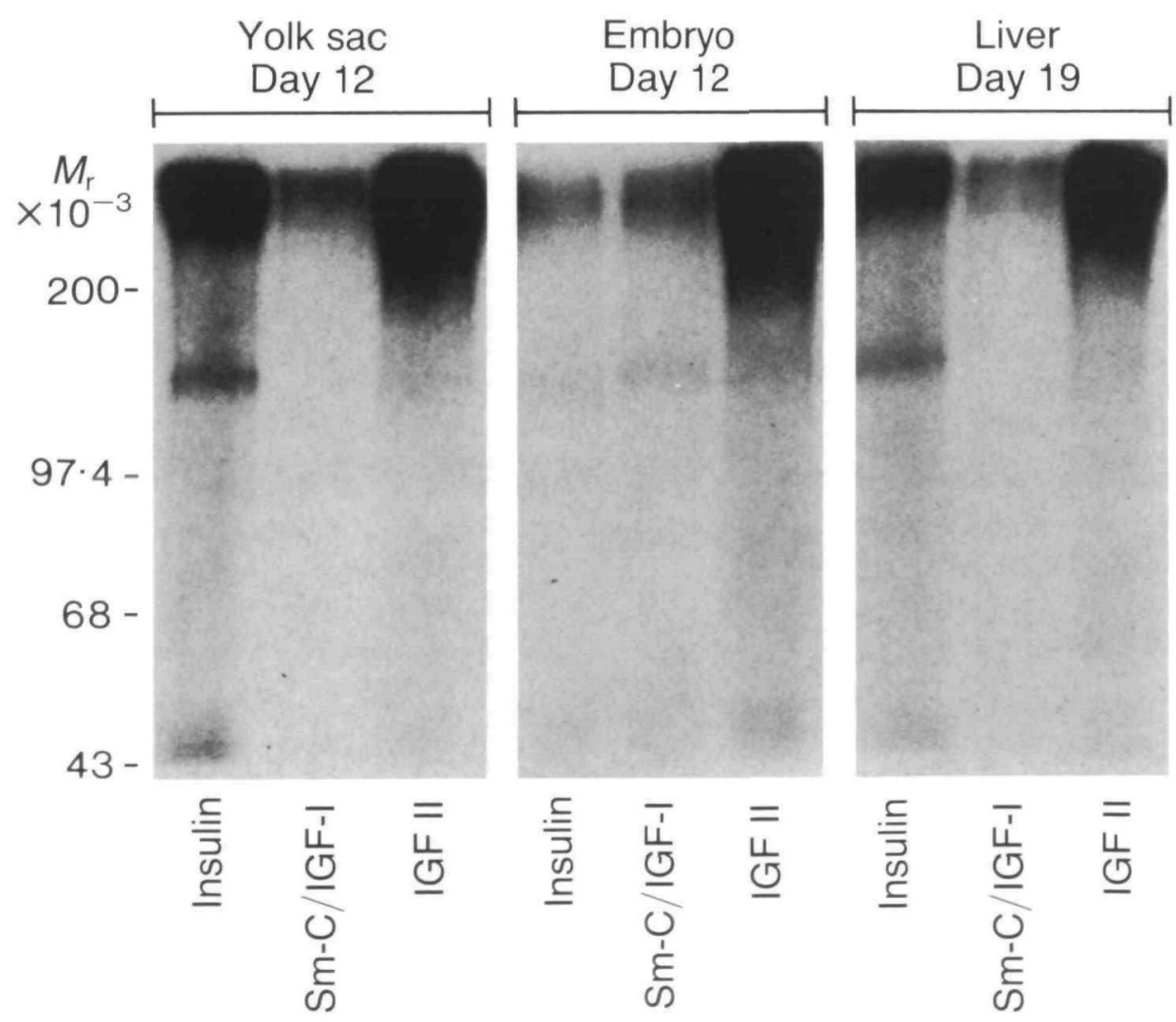

Fig. 2. Radiolabelled insulin, Sm-C/IGF-I and IGF-II affinity cross-linked to day-12 visceral yolk sac and embryonic membranes, and day-19 liver membranes. Radiolabelled complexes were resolved on $6 \%$ SDS-PAGE and autoradiographed. Membrane preparations are indicated above the appropriate lanes, radioligands cross-linked below lanes and the migration of molecular weight standard $\left(\times 10^{-3}\right)$ are depicted on the legend to the left. For ${ }^{125} \mathrm{I}$-insulin, $200 \mu \mathrm{g}$ of membrane protein was analysed, while $100 \mu \mathrm{g}$ was used for ${ }^{125} \mathrm{I}-\mathrm{Sm}-\mathrm{C} / \mathrm{IGF}-\mathrm{I}$ and ${ }^{125} \mathrm{I}-\mathrm{IGF}-\mathrm{II}$. All the samples were reduced with $2 \%$ 2-mercaptoethanol. Note that the ${ }^{125}$ I-IGF-II receptor complex is poorly resolved at the origin of the gel, as the electrophoresis was performed in a mini-vertical slab cell (Biorad Laboratories, Rockville Centre, New York, USA). 
the embryonic tissue. The ${ }^{125}$ I-labelled IGF-II complex, which in this autoradiogram is concentrated near the origin of the gel, is intensely labelled in all three tissues.

Soluble Sm/IGF binding proteins could be identified by cross-linking extracts of embryo homogenates from days 9 to 12 (Fig. 3). On reduced gels, a diffuse band of $35-40 \mathrm{~K}$ is observed (arrow, lane 1), whereas, in unreduced samples, two bands of about $30 \mathrm{~K}$ and $38 \mathrm{~K}$ (arrows, lane 5) are detected. The intensity of labelling of these complexes is diminished with competition with unlabelled Sm-C/IGF-I, but not with unlabelled insulin, indicating that these labelled complexes are specific. The higher molecular weight bands appreciated in the embryonic samples probably represent solubilized receptor complexes. In results not shown, affinity labelling of visceral yolk sac extracts revealed similar $\mathrm{Sm}-\mathrm{C} / \mathrm{IGF}-\mathrm{I}-$ binding proteins. Blastocysts also show evidence of lower molecular weight binding proteins of $35-40 \mathrm{~K}$ by affinity labelling (Fig. 3, lane 9), and there is no suggestion of any higher molecular weight receptor complexes despite a 2-month autoradiographic exposure.

\section{PC13 receptors and binding proteins}

When PC13 cells are affinity labelled with ${ }^{125} \mathrm{I}-\mathrm{Sm}$ C/IGF-I (Fig. 4, panel A), the alpha subunit of the type I Sm/IGF receptor is easily detectable both before (lane 1) and after treatment with retinoic acid (lane 5). The type II Sm/IGF receptor complex is labelled by ${ }^{125}$ I-IGF-II in the undifferentiated cells (lane 2), but much less so after differentiation (lane 6). ${ }^{125}$ I-insulin labelled the alpha subunit of the insulin receptor in the undifferentiated cells (lane 3 ), but there is no apparent labelling of this subunit after retinoic acid exposure (lane 7 ). In addition, PC13 cells elaborate $\mathrm{Sm} / \mathrm{IGF}$-binding proteins into their medium (Fig. 4, panel B). Affinity labelling of medium conditioned by undifferentiated cells showed an intensely labelled specific complex of about $40 \mathrm{~K}$ and a weakly labelled complex of about $50 \mathrm{~K}$ (lanes 1-4). Medium from differentiated cells displayed specifically labelled doublet complexes of 35 and $40 \mathrm{~K}$, and a less prominent complex at about $50 \mathrm{~K}$ (lanes 5-8).

\section{Evidence of somatomedin synthesis by embryos and PC13 cells}

Immunoreactive Sm-C/IGF-I was detected in extracts of day-10 and day-14 embryos (Table 1A), and in similar concentration when calculated on the basis of tissue protein. In addition, these concentrations are comparable to those of extracts of adult rat tissues (for example $0.07 \mathrm{pg} \mathrm{g}^{-1}$ tissue protein for liver, D'Ercole et al. 1984). Tissues from day 9 were not sufficiently large for adequate analysis. Both differentiated and undifferentiated $\mathrm{PC} 13$ cells elaborated immunoreactive Sm-C/IGF-I into their medium

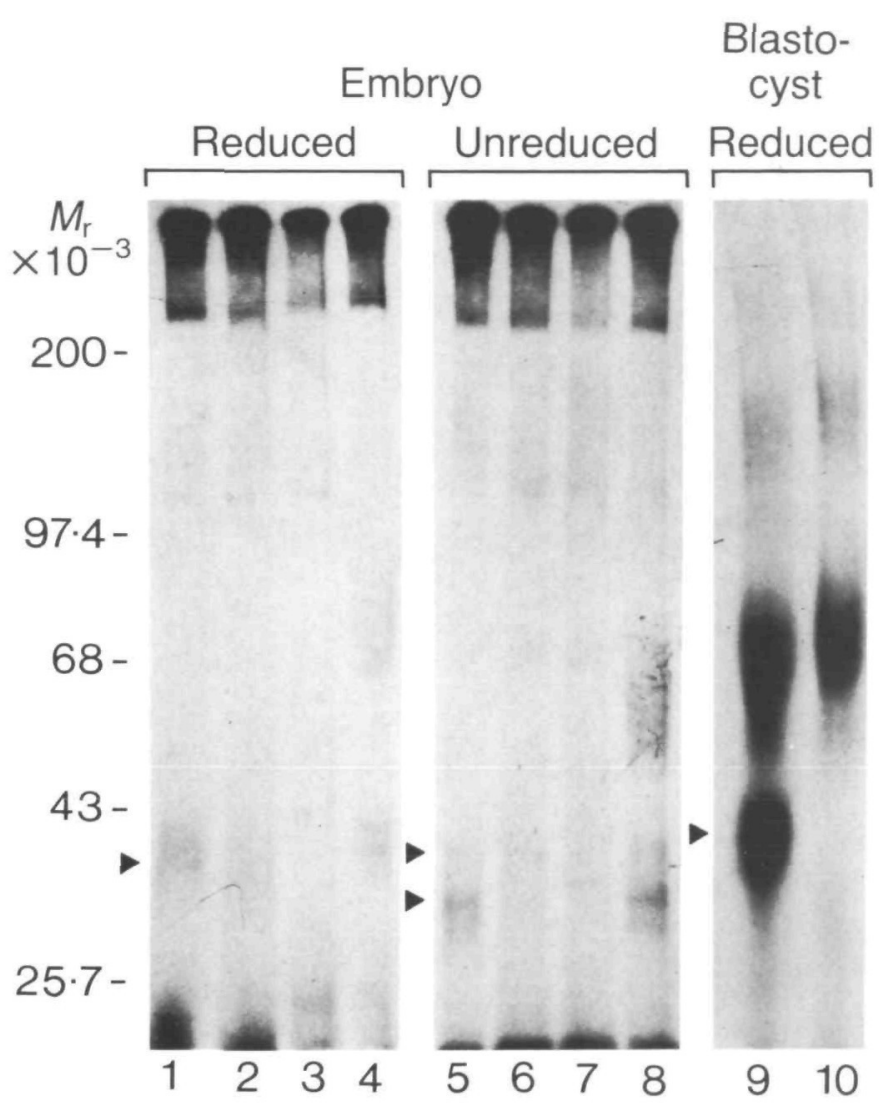

Fig. 3. Radiolabelled Sm-C/IGF-I affinity cross-linked to soluble fractions of day-11 embryos and blastocysts. Radiolabelled complexes were resolved on 6-14\% SDS-PAGE and autoradiographed. The migration of the molecular weight standards $\left(\times 10^{-3}\right)$ are depicted on the legend to the left. The source of the sample and whether or not it was reacted with $2 \% 2$-mercaptoethanol is indicated above the appropriate lanes. For soluble embryo fractions, $50 \mu \mathrm{g}$ of protein was analysed. Lanes 1 and 5 show the reaction with ${ }^{125} \mathrm{I}-\mathrm{Sm}-\mathrm{C} / \mathrm{IGF}-\mathrm{I}$ only. Lanes 2 and 6 show competition with unlabelled Sm$\mathrm{C} / \mathrm{IGF}-\mathrm{I}, 20 \mathrm{ng} \mathrm{ml}^{-1}$. Lanes 3 and 7 show competition with unlabelled Sm-C/IGF-I, $200 \mathrm{ng} \mathrm{ml}^{-1}$. Lanes 4 and 8 show competition with insulin, $200 \mathrm{ng} \mathrm{ml}^{-1}$. The arrow indicates the affinity-labelled complexes representing binding proteins. Higher molecular weight complexes represent residual membrane complexes present in the soluble fraction. Approximately 31 whole homogenized blastocysts are represented on lane 9 , while lane 10 is a control lane showing nonspecific cross-linking of ${ }^{125} \mathrm{I}-\mathrm{Sm}$ C/IGF-I to albumin in the buffer. Albumin was not present during the affinity-labelling reaction in any of the other experiments. The arrow pointing to the labelled binding protein complex in lane 9 has the same $M_{\mathrm{r}}$ as the complex indicated by the arrow in lane 1 (the figure is a composite of two different gels, consequently the migration of standards and complexes is slightly different). 

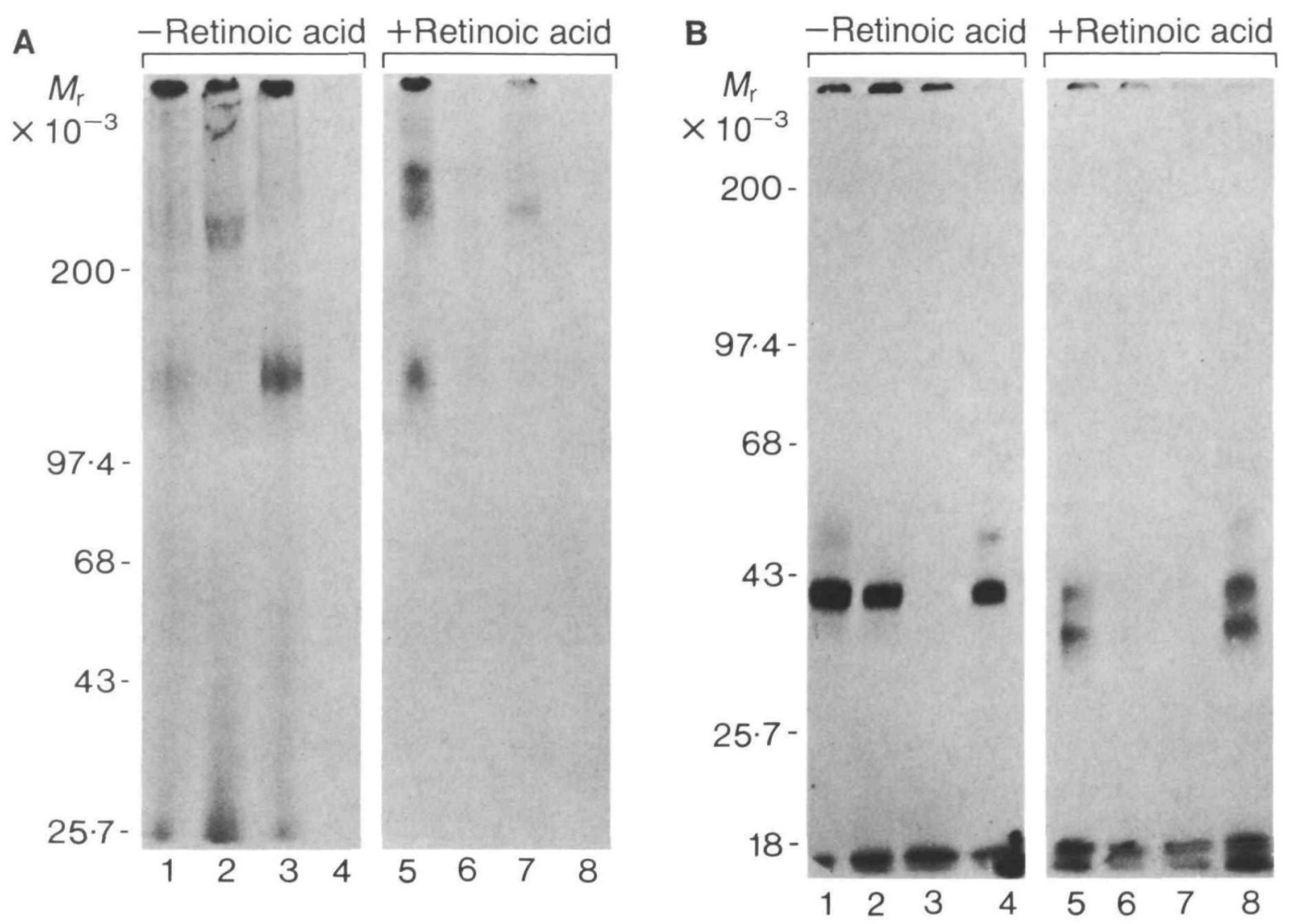

Fig. 4. Affinity cross-linked PC13 receptors (A) and binding proteins (B). (A) Radiolabelled Sm-C/IGF-I, IGF-II and insulin affinity cross-linked to $\mathrm{PC} 13$ cells grown to confluence with $(+)$ and without $(-)$ retinoic acid. After reduction with $2 \%$ 2-mercaptoethanol, the radiolabelled complexes were resolved on a 6-14\% SDS-PAGE and autoradiographed. Affinity labelling was performed while the cells were attached on the dishes as described in the methods. Lanes 1 and 5 show reaction with ${ }^{125} \mathrm{I}-\mathrm{Sm}$-C/IGF-I. Lanes 2 and 6 show labelling with ${ }^{125}$ I-IGF-II. Lanes 3 and 7 show labelling with ${ }^{125} \mathrm{I}$-insulin alone, whereas lanes 4 and 8 show labelling with ${ }^{125} \mathrm{I}$-insulin in the presence of unlabelled insulin (100 $\mathrm{ng} \mathrm{m}^{-1}$ ). (B) Radiolabelled Sm-C/IGF-I affinity cross-linked to conditioned media from PC13 cells grown to confluence with $(+)$ and without $(-)$ retinoic acid. Each lane represents $50 \mu$ l of conditioned medium. The radiolabelled complexes, after reduction with $2 \% 2$-mercaptoethanol, were resolved in a $3-14 \%$ SDS-PAGE and autoradiographed. Lanes 1 and 5 represent reaction with ${ }^{125} \mathrm{I}-\mathrm{Sm}-\mathrm{C} / \mathrm{IGF}-\mathrm{I}$ alone. Lanes 2 and 6 include reaction with unlabelled Sm-C/IGF-I $\left(20 \mathrm{ng} \mathrm{ml}^{-1}\right)$. Lanes 3 and 7 were reacted with unlabelled Sm-C/IGF-I $\left(100 \mathrm{ng} \mathrm{ml}^{-1}\right)$. Lanes 4 and 8 were reacted with unlabelled insulin $\left(100 \mathrm{ng} \mathrm{ml}^{-1}\right)$. The migration of molecular weight standards $\left(\times 10^{-3}\right)$ is depicted to left of each gel A and B.

Table 1. Immunoreactive Sm-C/IGF-I

(A) In embryo extracts

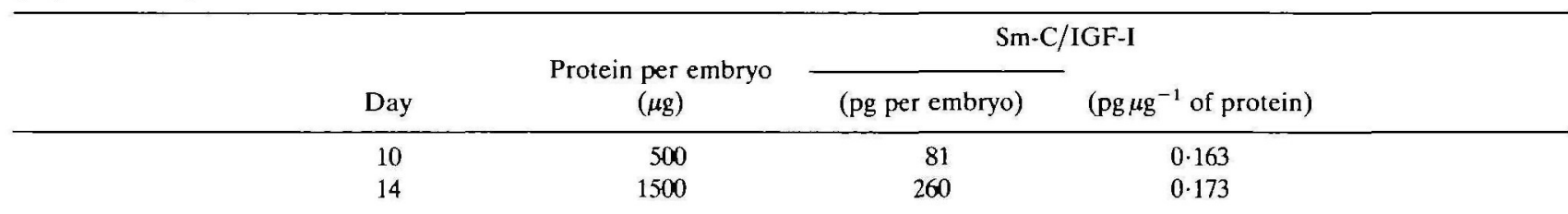

(B) In PC13-conditioned medium

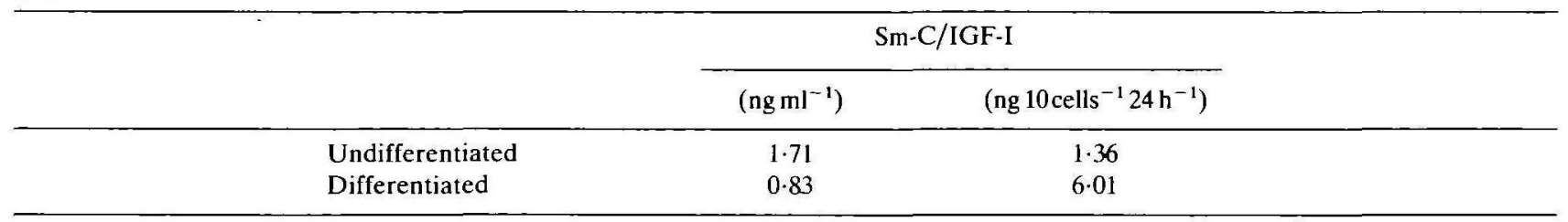


(Table 1B). When cell number was accounted for, the differentiated cells generated greater quantities of $\mathrm{Sm}$-C/IGF-I activity per $24 \mathrm{~h}$.

\section{Discussion}

Our data indicate that day- 9 to -12 mouse embryos possess both type I and II Sm/IGF receptors and in apparently greater abundance than the insulin receptors, while the visceral yolk sac appears to have a greater abundance of insulin receptors. In addition, embryos contain extractable Sm/IGF immunoreactivity and $\mathrm{Sm} / \mathrm{IGF}$-binding proteins. The presence of immunoreactive Sm/IGF's, Sm/IGF receptors and binding proteins in these tissues provides evidence of a role for Sm/IGF's during organogenesis.

The size and specificity characteristics of the receptors identified by affinity labelling are typical of those described in other tissues (Chernausek et al. 1981; Czech, 1982; Grizzard et al. 1984; Casella et al. 1986; Han, D'Ercole \& Lauder, 1987). As has been observed in other rodent tissues and cultured cells (Bhaumick \& Bala, 1985; Han et al. 1987; Pilstine, Moses \& Munro, 1984), ${ }^{125} \mathrm{I}-\mathrm{Sm}$-C/IGF-I can be cross-linked to the type II Sm/IGF receptor, suggesting that Sm-C/IGF-I has a higher affinity for this receptor in rodents than it does in man. Chemical affinity cross-linking studies, however, do not lend themselves well to quantification. The intensity of labelled complexes is dependent upon the number and affinity of the binding moiety, and, thus, conclusions must be made with caution. Our data, however, are consistent with other more quantitative studies. For example, human liver has abundant insulin and type II receptors, but a paucity of type I Sm-C/IGF-I receptors (Massague \& Czech, 1982), a result that is in agreement with our assessment of these receptors in day-19 mouse liver.

The apparent paucity of insulin receptors in embryonic tissues relative to those in visceral yolk sac agrees with the findings of Unterman who demonstrated greater insulin-specific binding to membrane preparations derived from rat extraembryonic tissues than from embryos (Unterman, Goewert, Baumann \& Freinkel, 1986). Similarly, in the day-2 chick embryo, which corresponds to day 11 of rat gestation, ${ }^{125}$ I-insulin-specific binding could not be detected, but ${ }^{125} \mathrm{I}-\mathrm{S} \mathrm{m}-\mathrm{C} / \mathrm{IGF}-\mathrm{I}$ specific binding was readily quantified (Bassas et al. 1985). Furthermore, insulin mRNA's cannot be detected in the rat until day 14 of gestation in the visceral yolk sac (Muglia \& Locker, 1984 ) and day 15 in the pancreas (Kakita, Giddings, Rotwein \& Permut, 1983), indicating that insulin is not synthesized during early gestation in the conceptus. Maternal insulin, however, may have access to the embryo prior to plancentation by traversing extraembryonic membranes bound to carrier proteins such as albumin (Rhinehardt, Carey, Young \& Klein, 1984). Therefore, it seems unlikely that insulin has a significant direct role during embryogenesis.

The Sm/IGF-binding proteins found in embryonic tissues are similar in size to a species of binding protein observed in rat (D'Ercole \& Wilkins, 1984) and human (Wilkins \& D'Ercole, 1985) serum, in human amniotic fluid (Drop, Kortleve \& Guyda, 1984), in media from cultured BRL cells (Romanus et al. 1986) and human fibroblasts (Clemmons et al. 1986). How these binding proteins alter Sm/IGF's biological activity is not clear. Several studies (Drop et al. 1979; Knauer \& Smith, 1980) have demonstrated that binding proteins inhibit the action of Sm/IGF on cultured cells. In studies of cultured human fibroblasts, however, Sm-C/IGF-I-binding protein complexes can be detected on the cell surface at times when these cells can respond to Sm-C/IGF-I, suggesting that these binding proteins may deliver SmC/IGF-I to its cell surface receptor. Given the capacity of such binding proteins to bind to the cell surface, it is not surprising to find these complexes associated with homogenates of blastocysts; their role, however, is entirely speculative.

The presence of immunoreactive Sm-C/IGF-I in extracts of day-10 and -14 embryos suggests they are capable of Sm/IGF synthesis. The antibody used to estimate the tissue content of Sm-C/IGF-I also detects rat IGF-II with a cross-reactivity of about $1.2 \%$ (Van Wyk, Svoboda \& Underwood, 1980). Because rat IGF-II serum concentrations are many fold higher than those of Sm-C/IGF-I during late gestation (15-21 days) (Moses et al. 1980) estimates of SmC/IGF-I tissue content may reflect in part crossreactivity with this peptide. Nevertheless, because this antibody does not cross-react significantly with any other known peptides, the immunoreactivity detected indicates the presence of Sm/IGF's. These data are consistent with other studies in the rat, where we have found immunoreactive Sm-C/IGF-I in late gestation fetal liver and lung (Vileisis \& D'Ercole, 1986) and where specific mRNA's for SmC/IGF-I and IGF-II were present in a number of fetal rat tissues from at least day 14 of gestation (Lund et al. 1986). In man, we have found Sm-C/IGF-I immunoreactivity in extracts of multiple fetal tissues (D'Ercole, Hill, Strain \& Underwood, 1986) from as early as 9 weeks gestation.

PC13 cells are considered analogous to stages of mouse embryonic development when the primitive germ layers are established (Martin \& Evans, 1975). Our data show that, in the undifferentiated state, they possess the three receptor populations studied and retain primarily the $\mathrm{Sm}-\mathrm{C} / \mathrm{IGF}-\mathrm{I}$ receptors upon differentiation with retinoic acid. These results 
suggest that PC13 cells do not completely duplicate embryonic growth and differentiation. Although our studies in embryonic tissues do not distinguish among receptors on differentiated and undifferentiated cells, all tissues in vivo appear to have an abundance of IGF-II receptors and detectable insulin receptors, in contrast to the paucity or absence of these receptors in differentiated PC13 cells. Others have reported the induction of insulin receptors in the differentiated PC13 cell line (Heath et al. 1981) and the presence of more Sm-C/IGF-I receptors in this line prior to differentiation (Heath \& Shi, 1986). While in another embryonal carcinoma cell line (F9), insulin receptors predominate in the undifferentiated state (Nagarajan \& Anderson, 1982) and IGF-II receptors are diminished in the differentiated cells (Nagarajan et al. 1985). These discrepant findings may reflect genetic instability in the lines employed by different investigators.

As has been reported for F9 cells (Nagarajan et al. 1985) PC13 cells also appear to synthesize Sm/IGF's and binding proteins for Sm/IGF's. Recently, Heath \& Shi (1986) reported similar findings. The changes observed in the Sm/IGF-binding proteins after differentiation may represent a model for evaluating the regulation of $\mathrm{Sm} /$ IGF-binding proteins and the role of binding proteins in the control of $\mathrm{Sm} / \mathrm{IGF}$ action. For example, differentiated PC13 cells have been shown to be more responsive to Sm/IGF's than undifferentiated cells (Heath \& Deller, 1983). Perhaps binding proteins influence this response.

Our findings suggest - a possible role for Sm/IGF's in organogenesis. We have presented evidence for a role for Sm-C/IGF-I in regenerative renal growth following unilateral nephrectomy in the rat (Stiles, Sosenko, D'Ercole \& Smith, 1985). We found that $\mathrm{Sm}-\mathrm{C} / \mathrm{IGF}-\mathrm{I}$ levels increased in the remaining kidney during the regenerative period, a finding confirmed by Fagin \& Melmed (1986) when they demonstrated marked increases in the Sm-C/IGF-I mRNA's in the regenerating kidney. It is appealing to speculate that organ regeneration and organogenesis are analogous processes and that $\mathrm{Sm}$ /IGF's participate in each.

We wish to acknowledge the help of Drs Kathleen K. Sulik and Randall W. Williams during the course of these studies. We thank Lori Ann Bono for helping type the manuscript. E.P.S. is the recipient of a NIH Clinical Investigator Award HD00689. A.J.D. is a recipient of a Research Career Development Award from the NICHHD (HD00435). This work was supported by a basic research grant from the March of Dimes (1-758) to A.J.D. and USPHS grants HD08299 to A.J.D. and HD19593 to T.W.S.

\section{References}

Adamson, E. D. \& Hogan, B. L. M. (1984). Expression of EGF receptor and transferrin by $\mathrm{F} 9$ and $\mathrm{PC} 13$ teratocarcinoma cells. Differentiation 27, 152-157.

Bassas, L., de Pablo, F., Lesniak, M. A. \& Roth, J. (1985). Receptors for insulin-like peptides in chick embryo tissues: early dominance of insulin-like growth factor over insulin receptors in brain. Endocrinology 117, 2321-2329.

Bernstine, E. G., Hooper, M. L., Grandchamp, S. \& EPhrussi, B. (1975). Alkaline phosphatase activity in Mouse Teratoma. Proc. natn. Acad. Sci. U.S.A. 70, 3899-3903.

Bhaumick, B. \& Bala, R. M. (1985). Ontogeny and characterization of basic somatomedin receptors in rat placenta. Endocrinology 116, 492-498.

Casella, S. J., Han, V. K. M., D'Ercole, A. J., Svoboda, M. E. \& VAN WYK, J. J. (1986). Insulin-like growth factor II binding to the type I somatomedin receptor: evidence for two high affinity binding sites. $J$. biol. Chem. 261, 9268-9273.

Chernausek, S. D., JAcobs, S. \& VAN WyK, J. J. (1981) Structural similarities between human receptors for somatomedin- $\mathrm{C}$ and insulin: analysis by affinity labeling. Biochemistry 20, 7345-7350.

Clemmons, D. R., Elgin, R. G., Han, V. K. M., Casella, S. J., D'Ercole, A. J. \& Van Wyk, J. J. (1986). Cultured fibroblast monolayers secrete a protein that alters the cellular binding of somatomedinC/insulin-like growth factor-I. J. clin. Invest. 77, $1548-1558$.

Czech, M. P. (1982). Structural and functional homologies in the receptors for insulin and the insulinlike growth factors. Cell 31, 8-10.

D'Ercole, A. J., Hill, D. J., Strain, A. J. \& UNDERwOOD, L. E. (1986). Tissue and plasma somatomedin-C/insulin-like growth factor I concentrations in the human fetus during the first half of gestation. Pediatric Research 20, 253-255.

D’Ercole, A. J., Stiles, A. D. \& Underwood, L. E. (1984). Tissue concentrations of somatomedin-C: further evidence for multiple sites of synthesis and paracrine/autocrine mechanisms of action. Proc. natn. Acad. Sci. U.S.A. 81, 935-939.

D’Ercole, A. Jः \& Wilkins, J. R. (1984). Affinity labeled somatomedin-C binding proteins in rat sera. Endocrinologì 114, 1141-1144.

Drop, S. L. S., Kortleye, D. J. \& Guyda, H. J. (1984). Isolation of a somatomedin-binding protein from preterm amniotic fluid. Development of a radiormmunoassay. J. clin. Endocrinol. Metab. 59, 889-907.

Drop, S. L. S., Valiquette, G., Guyda, H. J., Corvol, M. T. \& Posner, B. I. (1979). Partial purification and characterization of a binding protein for insulin-like activity in human amniotic fluid: a possible inhibitor of insulin-like activity. Acta Endocrinol. 90, 505-518.

FAGIN, J. A. \& MELmEd, S. (1986). Relative increase of insulin-like growth factor-I mRNA levels in compensatory renal hypertrophy. Clin. Res. 34, 58A. 
Furlanetto, R. W., Underwood, L. E., Van Wyk, J. J. \& D'ERCole, A. J. (1977). Estimation of somatomedin$\mathrm{C}$ in normals and patients with pituitary disease by radioimmunoassay. J. clin. Invest. 60, 648-657.

Grizzard, J. D., D'Ercole, A. J., Wilkins, J. W., Moats-StaAts, B. M. \& Williams, R. W. (1984) Affinity-labeled somatomedin-C receptors and binding proteins from the human fetus. J. clin. Endocrinol. Metab. 58, 535-543.

Han, V. K. M., D'Ercole, A. J. \& Lauder, J. M. (1986). Characterization of Somatomedin/insulin-like growth factor receptors and correlation with biological activity in cultured neonatal rat astroglial cells. $J$. Neurosci. 7, 501-511.

Heath, J. K., Bell, S. \& Rees, A. R. (1981). Appearance of functional insulin receptors during the differentiation of embryonal carcinoma cells. J Cell Biol. 91, 293-297.

Heath, J. \& Deller, M. J. (1983). Serum-free culture of PC13 murine embryonal carcinoma cells. J. cell. Physiol. 115, 225-230.

Heath, J. K. \& Shi, W.-K. (1986). Developmentally regulated expression of insulin-like growth factors by differentiated murine teratocarcinomas and extraembryonic mesoderm. J. Embryol. exp. Morph. 95 , 193-212.

Kakita, K., Giddings, S. J., Rotwein, P. S. \& Permut, M. A. (1983). Insulin gene expression in the developing rat pancreas. Diabetes 32, 691-696.

KNAUER, D. J. \& SMITH, G. L. (1980). Inhibition of biological activity of multiplication-stimulating activity by binding to its carrier protein. Proc. natn. Acad. Sci. U.S.A. 77, 7252-7256.

LAEMmLi, U. K. (1970). Cleavage of structural proteins during the assembly of the head of bacteriophage T4. Nature, Lond. 227, 680-685.

Lowry, O. H., Rosebrough, N. J., Farr, A. L. \& RaNdall, R. J. (1951). Protein measurement with Folin phenol reagent. J. biol. Chem. 193, 265-275.

Lund, P. K., Moats-Staats, B. M., Hynes, M. A., Simmons, J. G., Jansen, M., D'Ercole, A. J. \& Van WYK, J. J. (1986). Somatomedin-C/IGF-I and IGF II mRNA's in fetal and adult tissues. J. biol. Chem. 261, $14539-14544$.

Maller, J. L. (1985). Regulation of amphibian oocyte maturation. Cell Differentiation 16, 211-221.

Martin, G. R. \& Evans, M. J. (1975). Differentiation of clonal lines of teratocarcinoma cells: Formation of embryoid bodies in vitro. Proc. natn. Acad. Sci. U.S.A. 72, 1441-1445.

Massague, J. \& Czech, M. P. (1982). The subunit structure of two distinct receptors for insulin-like growth factors I and II and their relationship to the insulin receptor. J. biol. Chem. 257, 5038-5041.

Milner, R. D. G. \& Hill, D. J. (1984). Fetal growth control: the role of insulin and related peptides. Clin. Endocrinol. 21, 415-433.

Moses, A. C., Nissley, S. P., Short, P. A., Rechler, M. M., WhITE, R. M., KNIGHT, A. B. \& Higam, O. Z. (1980). Elevated levels of multiplication-stimulating activity, an insulin-like growth factor, in fetal rat serum. Proc. natn. Acad. Sci. U.S.A. 77, 3649-3653.

Muglia, L. \& LoCker, J. (1984). Extrapancreatic insulin gene expression in the fetal rat. Proc. narn. Acad. Sci. U.S.A. 81, 3635-3639.

Nagarajan, L. \& Anderson, W. B. (1982). Insulin promotes the growth of F9 embryonal carcinoma cells apparently by acting through its own receptor. Biochem. Biophys. Res. Commun. 106, 974-980.

Nagarajan, L., Anderson, W. B., Nissley, S. P., Rechler, M. M. \& Jetten, A. M. (1985). Production of insulin-like growth factor II (MSA) by endodermlike cells derived from embryonal carcinoma cells: possible mediator of embryonic growth. J. cell. Physiol. 124, 199-206.

Pilstine, S. J., Moses, A. C. \& Munro, H. N. (1984). Insulin-like growth factor receptors in rat placental membranes. Endocrinology 115, 1060-1065.

Rees, A. R., Adamson, E. D. \& Graham, C. F. (1979). Epidermal growth factor receptors increase during the differentiation of embryonal carcinoma cells. Nature, Lond. 281, 309-311.

Rhinehardt, A. E., Carey, S. W., Young, M. F. \& KLEIN, N. W. (1984). Uptake and distribution of exogenous serum proteins in the cultured rat embryo. J. exp. Zool. 232, 379-383.

Romanus, J. A., Terrell, J. E., YanG, Y. W. H., Nissley, S. P. \& Rechler, M. M. (1986). Insulin-like growth factor carrier proteins in neonatal and adult serum are immunologically different: demonstration using a new radioimmunoassay for carrier protein from BRL-3A rat liver cells. Endocrinology 118, 1743-1757.

Rosenblum, I. Y., Matrson, B. A. \& Heyner, S. (1986). Stage-specific insulin binding in mouse preimplantation embryos. Devl Biol. 116, 261-263.

Smith, E. P., Svoboda, M. E., Van Wyk, J. J., Kierszenbaum, A. L. \& Tres, L. L. (1987). Partial characterization of a somatomedin-like peptide from the medium of cultured rat Sertoli cells. Endocrinology 120, 186-193.

Stiles, A. D., Sosenko, I. R. S., D'Ercole, A. J. \& SмrтH, B. T. (1985). Relation of kidney tissue somatomedin-C/insulin-like growth factor-I to postnephrectomy renal growth in the rat. Endocrinology 117, 2397-2401.

Stuart, C. A., Pietrzyk, R., Siu, A. K. \& Furlanetto, R. W. (1984). Size discrepancy between somatomedin$\mathrm{C}$ and insulin receptors. J. clin. Endocrinol. Metab. 58, $1-5$.

Svoboda, M. E. \& VAN WYK, J. J. (1985). Purification of somatomedin-C/insulin-like growth factor-I. In Methods in Enzymology, vol. 109 (ed. B. O'Malley \& L. Birnbaumer), pp. 798-816. New York: Academic Press.

Underwood, L. E. \& D'Ercole, A. J. (1984). Insulin and somatomedins/insulin like growth factors in fetal and neonatal development. In Clinics in Endocrinology and Metabolism, vol. 13, Tissue Growth Factors (ed. W. 
H. Daughaday), pp. 68-89. East Sussex, England: W. B. Saunders Co. Ltd.

Unterman, T., Goewert, R. R., Baumann, G. \& Freinkel, N. (1986). Insulin receptors in embryo and extraembryonic membranes of early somite rat conceptus. Diabetes 35, 1193-1199.

Wilkins, J. R. \& D'Ercole, A. J. (1985). Affinitylabeled plasma somatomedin-C/insulin-like growth factor-I binding proteins: evidence of growth hormone dependence and subunit structure. J. clin. Invest. 75, 1350-1358.
VAN WyK, J. J., Svoboda, M. E. \& UNderwood, L. E. (1980). Evidence from radioligand assays that somatomedin- $\mathrm{C}$ and insulin-like growth factor I are similar to each other and different from other somatomedins. J. clin. Endocrinol. Metab. 50, 206-208.

Vileisis, R. A. \& D'Ercole, A. J. (1986). Tissue and serum concentrations of somatomedin-C/insulin-like growth factor-I in fetal rats made growth retarded by uterine artery ligation. Pediatr. Res. 20, 126-130.

(Accepted 20 May 1987) 